\title{
Deskripsi Pengetahuan Konten Pedagogi Mahasiswa Calon Guru Jurusan Matematika FMIPA UNM
}

\author{
Awi Dassa ${ }^{1, a)}$, Fajar Arwadi, ${ }^{1, b)}$ dan Andi Rafiqa Faradiyah ${ }^{1, c)}$ \\ ${ }^{1}$ Jurusan Matematika, Fakultas MIPA, Universitas Negeri Makassar \\ a) awidassa@ gmail.com, \\ b)fajararwadi53@gmail.com, \\ c)andirafiqafaradiyah@gmail.com,
}

\begin{abstract}
Abstrak. Penelitian ini bertujuan mendeskripsikan pengetahuan konten pedagogi mahasiswa Jurusan Matematika FMIPA UNM dengan indikator pengetahuan penguasaan materi, pengetahuan pedagogi, serta pengetahuan subjek terkait peserta didiknya. Subjek dari penelitian ini adalah mahasiswa Jurusan Matematka FMIPA UNM. Jenis penelitian yang digunakan adalah pendekatan kuantitatif dan kualitatif (Mix Method). Data dikumpulkan dengan memberikan soal tes pengetahuan konten pedagogi kepada 45 orang subjek dan melakukan wawancara semi terstuktur kepada 2 subjek yang dipilih secara acak. Setelah memperoleh informasi terkait kategori level PCK subjek, analisis terkait jawaban-jawaban yang diberikan oleh subjek untuk mendeskripsikan alasan-alasan subjek memperoleh level PCK yang dimaksud. Hasil penelitian menunjukkan bahwa tidak ada mahasiswa yang memperoleh level PCK yang tinggi.
\end{abstract}

Kata Kunci: Pengetahuan Konten Pedagogi, Pengetahuan Materi, Pengetahuan Pedagogi, Pengetahuan tentang Peserta didik, Bangun Datar.

Abstract. This study aims to describe the pedagogical content knowledge of Mathematics and Natural Sciences Department students of FMIPA with indicators of mastery knowledge, pedagogy knowledge, and subject knowledge related to their students. The subjects of this study were students of the Mathematics Department FMIPA UNM. This type of research is a quantitative and qualitative approach (Mix Method). Data was collected by giving pedagogical content knowledge test questions to 45 subjects and conducting semi-structured interviews to 2 randomly selected subjects. After obtaining information related to the subject's PCK level category, an analysis of the answers provided by the subject to describe the reasons the subject obtained the intended PCK level. The results showed that there were no students who obtained high levels of PCK..

Keywords: Pedagogical Content Knowledge, Material Knowledge, Pedagogical Knowledge, Student Knowledge, Two Dimentional Figure.

\section{PENDAHULUAN}

Undang-Undang Republik Indonesia Nomor 14 Tahun 2005 tentang Guru Dan Dosen menuntut guru untuk memiliki kualifikasi akademik, kompetensi, sertifikat pendidik, sehat jasmani dan rohani, serta memiliki kemampuan untuk mewujudkan tujuan pendidikan nasional. Salah satu kompetensi yang disebutkan dalam undang-undang tersebut adalah kompetensi pedagogi.

Kompetensi pedagogi merupakan salah satu hal penting yang harus dimiliki seorang guru dalam menyelenggarakan pembelajaran yang efektif untuk mencapai tujuan pendidikan. Kompetensi pedagogi merupakan kemampuan seseorang dalam mengajar yang mencakup berbagai aspek terkait dengan ilmu mendidik, keterampilan dasar mengajar dan pengelolaan kelas agar kegiatan 
pembelajaran dapat berjalan secara efektif bagi para siswa (Indirani, 2016). Kompetensi pedagogik sebagai kemampuan seorang pendidik dalam mengelola pembelajaran peserta didik yang meliputi; (1) kemampuan dalam memahami peserta didik; (2) kemampuan dalam merancang pembelajaran; (3) kemampuan melaksanakan pembelajaran; (4) kemampuan mengevaluasi proses dan hasil pembelajaran (Yasin,2008).

Salah satu konsep yang menggunakan kompetesi pedagogi sebagai aspek utamanya yakni konsep Pengetahuan Konten Pedagogi atau PCK (Pedagogical content Knowledge). PCK adalah pengetahuan dasar yang harus dimiliki seorang guru agar dapat menciptakan suasana pembelajaran yang efektif. PCK adalah cara guru untuk mewakili dan merumuskan pengetahuan subjek-materi ketika sedang memberikan pempembelajaran kepada peserta didik (Shulman, 1989).

Beberapa penelitian terkait PCK telah di lakukan. Turnuklu \& Yesildere (2014) meneliti tentang hubungan antara pengetahuan matematika dan pengetahuan mengajar matematika (PCK). Selain itu, ada juga penelitian yang dilakukan oleh Purwianingsih,dkk (2011) terkait kesulitan yang sering dialami oleh calon guru, salah satunya adalah mengintegrasikan pedagogical knowledge dengan content knowledge.

Penelitian ini juga berfokus kepada PCK. Tujuan dari penelitian ini adalah untuk mendeskripsikan kemampuan PCK mahasiswa calon guru di Universitas Negeri Makassar dalam aspek pengetahuan penguasaan materi, pengetahuan pedagogi/strategi pembelajaran, dan pengetahuan mahasiswa tentang peserta didik yang diajar.

\section{KAJIAN PUSTAKA}

Pengetahuan Konten Pedagogi (PCK) adalah penjabaran konsep yang mudah dipahami, analogi, ilustrasi, contoh, penjelasan dan demonstrasi yang efektif, cara merepresentasikan dan memformulasikan suatu hal sehingga mudah dipahami oleh orang lain (Shulman, 1986). Terdapat tujuh pengetahuan profesional yang mesti dimiliki oleh seorang guru: pengetahuan materi, pengetahuan pedagogi, PCK, pengetahuan tentang peserta didik, pengetahuan kurikulum, pengetahuan konteks pendidikan, dan pengetahuan filosofi dan tujuan pendidikan (Shulman, 1987).

Mengukur kemampuan PCK perlu didasarkan atas beberapa aspek. Aspek-aspek PCK telah dijabarkan oleh beberapa ahli seperti Smith dan Neale (1989), Grossman (1990), Cochran, de Ruiter, \& King (1993), (Magnusson dkk, 1999). Penelitian ini berfokus pada 3 aspek, yakni 1) Pengetahuan Penguasaan Materi, 2) Pengetahuan Pedagogi, dan 3) Pengetahuan tentang Peserta Didik.

Aspek pertama, pengetahuan penguasaan materi. Pengetahuan materi merujuk pada pengetahuan matematika, representasi matematika dalam pembelajaran, dan kemampuan mengerjakan soal. (Hurrel, 2013; Kim, 2004; Turnuklu \& Yesildere, 2007).

Kedua, pengetahuan pedagogi/strategi pembelajaran. Smith dan Neale (1989) menyatakan bahwa pengetahuan tersebut mencakup kemampuan untuk memahami prekonsepsi atau dugaan jawaban dari peserta didik, kemampuan mengklarifikasi, memunculkan debat dan diskusi, dan menyajikan penjelasan alternatif. Sedangkan Lim (2007) mengemukakan pengetahuan strategi termasuk dalam kemampuan pedagogi guru dapat dilihat dari kemampuannya dalam merencanakan pembelajaran; menentukan strategi pengajaran; memilih konten yang sesuai dengan pemahaman peserta didik.

Ketiga, pengetahuan tentang peserta didik. Pengetahuan ini mencakup konsepsi, miskonsepsi, kesalahan, dan kesulitan peserta didik. Pengetahuan tentang peserta didik adalah perkembangan kognitif atau bagaimana peserta didik belajar mengenai suatu topik (Smith \& Neale (1989); Cochran, dkk (1993); Magnusson, Krajcik, \& Borko, (1999)). Indikator-indikator tersebut juga 
didukung oleh Fennema dan Franke (1992) bahwa pengetahuan peserta didik diantaranya adalah pemahaman, konsepsi, miskonsepsi, kesalahan dan kesulitan umum oleh peserta didik.

Tiga aspek tersebut dipilih berdasarkan beberapa alasan. Pertama, aspek-aspek tersebut terkait langsung dengan kemampuan mahasiswa dalam pelaksanaan pembelajaran di kelas. Kedua, pengetahuan tersebut sesuai dengan anggapan Shulman bahwa PCK bergantung pada pengetahuan guru tentang materi pelajaran, pengetahuan pedagogi, dan bagaimana menggunakan pengetahuan tersebut untuk dapat memahamkan peserta didik tentang materi pelajaran tersebut pada kondisi dan situasi apapun.

Turnuklu \& Yesildere (2014) meneliti tentang hubungan pengetahuan matematika dan pengetahuan mengajar matematika (PCK). Penelitiannya menunjukkan bahwa memang diperlukan pemahaman yang mendalam tentang pengetahuan matematika, namun pengetahuan pemahaman saja tidak cukup untuk mengajar matematika. Penelitian tersebut menunjukkan bahwa hubungan antara pengetahuan matematika dan pengetahuan mengajar matematika (PCK) dan menyarankan calon guru matematika dasar harus dididik baik dari aspek pengetahuan matematika dan aspek PCK.

Selain itu, Purwianingsih,dkk (2010) pernah meneliti tentang kesulitan yang dialami oleh calon guru. Hasil penelitiannya calon guru sering mengalami kesulitan dalam mengintegrasikan pedagogical knowledge dengan content knowledge. Sehingga seorang guru tidak hanya harus menguasai materi atau pengetahuan konten saja namun harus mengetahui bagaimana mengintegrasikan pengetahuan konten tersebut dengan pengetahuan tentang kurikulum, pembelajaran, dan karakteristik siswa

\section{METODE PENELITIAN}

Penelitian ini menggunakan Mix Method yang terdiri dari pendekatan kuantitatif dan kualitatif. Subjek dalam penelitian ini adalah 45 orang mahasiswa jurusan Matematika pada pendekatan kuantitatif, dan diambil 2 orang dari subjek tersebut untuk diwawancarai lebih lanjut secara kualitatif.

Teknik pengumpulan data dalam penelitian ini adalah tes dan wawancara. Instrumen penelitian yang digunakan adalah instrumen tes PCK dan pedoman wawancara yang sebelumnya telah divalidasi oleh ahli.

45 orang subjek terlebih dahulu diberikan tes PCK. Hasil tes PCK dihitung, kemudian berdasarkan nilai yang berhasil mereka peroleh, subjek dikategorikan ke level PCK seperti pada Tabel 1.

Setelah memperoleh informasi terkait kategori level PCK subjek. Dilakukan analisis terkait jawaban-jawaban yang diberikan oleh subjek untuk mendeskripsikan alasan-alasan subjek memperoleh level PCK yang dimaksud. Informasi pada hasil tes PCK yang dianggap kurang medalam, dijadikan sebagai catatan untuk bahan wawancara yang dilakukan kepada 2 orang subjek yang dipilih secara random. Selain menggali informasi lebih dalam, wawancara juga dilakukan untuk mengonfirmasi jawaban subjek pada hasil tes PCK. 
TABEL 1. Pedoman Kategorisasi Level PCK.

\begin{tabular}{|c|c|c|}
\hline Range Nilai & Level & Keterangan \\
\hline $14-20$ & Level 1 (Kurang) & $\begin{array}{l}\text { 1. Sulit memahami kesulitan siswa dan } \\
\text { alasan siswa kesulitan } \\
\text { 2. Tidak mampu memahami proses } \\
\text { berpikir siswa dengan pertanyaan atau } \\
\text { memiliki kemampuan untuk } \\
\text { menciptakan solusi untuk kesulitan } \\
\text { belajar siswa } \\
\text { 3. Kesulitan untuk membentuk kriteria } \\
\text { yang tepat untuk penilaian dan tidak } \\
\text { menilai jawaban siswa sesuai dengan } \\
\text { kriteria ini. }\end{array}$ \\
\hline $21-35$ & Level 2 (Baik) & $\begin{array}{l}\text { 1. Memahami kesulitan siswa dan alasan } \\
\text { siswa mengalami kesulitan tersebut } \\
\text { 2. Gagal mengajukan pertanyaan yang } \\
\text { tepat dan bermakna untuk memahami } \\
\text { proses pemikiran mereka } \\
\text { 3. Kesulitan untuk menciptakan solusi } \\
\text { untuk kesalahpahaman } \\
\text { 4. Memiliki kesulitan untuk membentuk } \\
\text { kriteria yang tepat untuk penilaian dan } \\
\text { menilai siswa jawaban sesuai kriteria. }\end{array}$ \\
\hline $36-42$ & Level 3 (Sangat Baik) & $\begin{array}{l}\text { 1. Memahami kesulitan siswa dan } \\
\text { memahami alasan mengapa siswa } \\
\text { tersebut mengalami kesulitan } \\
\text { 2. Mampu mengajukan pertanyaan yang } \\
\text { tepat dan bermakna untuk memahami } \\
\text { pemikiran mereka mengenai proses. } \\
\text { 3. Memiliki kemampuan untuk } \\
\text { menciptakan solusi untuk mengatasi } \\
\text { kesulitan belajar siswa. } \\
\text { 4. Membentuk kriteria yang sesuai untuk } \\
\text { penilaian dan menilai jawaban siswa } \\
\text { sesuai untuk kriteria ini. }\end{array}$ \\
\hline
\end{tabular}

\section{HASIL DAN PEMBAHASAN}

Pada bagian ini dipaparkan hasil penelitian berupa kategori level PCK subjek berdasarkan hasil tes PCK dan transkrip wawancara. Pembahasan hasil penelitian akan dibahas secara umum kemudian dijabarkan khusus pada tiap-tiap indikator.

TABEL 2. Hasil tes PCK.

\begin{tabular}{ccc}
\hline Levels & F & Persentase (\%) \\
\hline Level 1 (Rendah) & 10 & 22,22 \\
Level 2 (Baik) & 35 & 77,78 \\
Level 3 (Sangat Baik) & 0 & 0 \\
Total & 45 & 100 \\
\hline
\end{tabular}

Hasil tes PCK 45 orang mahasiswa disajikan pada Tabel 2. Sebagian besar mahasiswa berada dalam kategori baik, dan tidak terdapat mahasiswa yang masuk dalam kategori sangat baik. Hal ini disebabkan karena subjek tidak mendapatkan materi khusus terkait PCK pada bangku peruruan tinggi. Penjabaran terkait masing-masing indikator akan dijelaskan lebih lanjut. 


\section{Indikator Pengetahuan Subjek Terkait Penguasaan Materi}

Hasil pekerjaan subjek terkait penguasaan materi mereka disajikan pada Tabel 3.

TABEL 3. Persentase Indikator Penguasaan Materi.

\begin{tabular}{ccccccc}
\hline & \multicolumn{5}{c}{ Point yang diberikan } \\
\cline { 2 - 7 } & \multicolumn{2}{c}{ 3 Poin } & \multicolumn{2}{c}{ 2 Poin } & \multicolumn{2}{c}{ 1 Poin } \\
\cline { 2 - 7 } & Jumlah & Persentase & Jumlah & Persentase & Jumlah & Persentase \\
\hline Problem 1-A & 27 & $60 \%$ & 4 & $8 \%$ & 14 & $32 \%$ \\
Problem 2-B & 16 & $35,6 \%$ & 19 & $42,2 \%$ & 10 & $22,2 \%$ \\
Problem 3-B & 2 & $4 \%$ & 8 & $17,8 \%$ & 35 & $77,8 \%$ \\
Problem 4-A & 5 & $11,1 \%$ & 21 & $46,7 \%$ & 19 & $42,2 \%$ \\
\hline
\end{tabular}

Pada Tabel 3, materi yang paling dikuasai subjek adalah materi pada soal 1-A tentang perbandingan sudut dan sisi pada segitiga, kemudian 2-B tentang kekongruenan, lalu 4-A tentang sudut pusat dan sudut keliling lingkaran, terakhir adalah 3-B tentang sifat dasar bangun datar.

Hal ini menunjukkan bahwa pengetahuan subjek terkait materi pembelajaran belum merata, ada beberapa materi yang dikuasai, ada juga yang tidak dipahami sama sekali. Berikut disajikan salah satu paparan jawaban subjek terkait pemahaman materi:

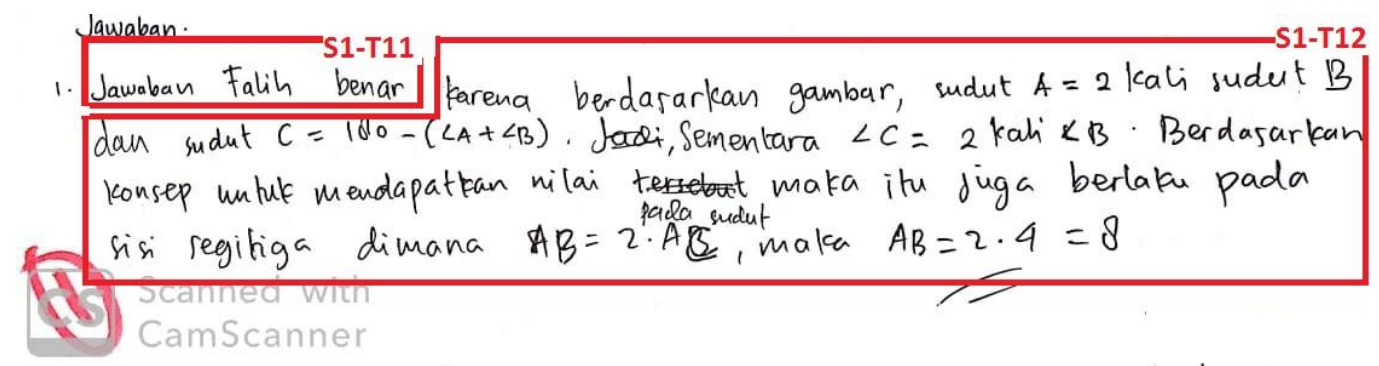

GAMBAR 1. Paparan Jawaban Subjek A-Soal No 1.

Berdasarkan penjabarannya, subjek menganggap bahwa jawaban yang diberikan sudah benar dengan alasan bahwa apabila besarnya sudut segitiga 2 kali lipat, maka panjang sisi di depan sudut juga akan menjadi 2 kali lipat (S1-T12). Jawaban yang diberikan subjek salah karena panjang sisi segitiga tidak bergantung pada sudut di hadapannya. Hal ini menunjukkan bahwa pengetahuan subjek terkait materi masih kurang.

Saat dilakukan wawancara kepada subjek, subjek memberikan pernyataan seperti pada Transkrip 1.

TRANSKRIP 1.

S1-W065 Karena menurut ku, pasnya saya kerjakan ini soalnya, awalahnya sepemikiran ka sama Falih.

Kan dijawabanku ini sudah mi saya jelaskan toh misalnya sudut $\mathrm{C}=2 \mathrm{~B}$, ini sudut $\mathrm{A}=2 \mathrm{~B}$, sudut $\mathrm{C}$ ini sebenarnya maksudku tapi kesalahan tekniska disini, saya yang salah. Terus disini sudut $\mathrm{C}=2 \mathrm{~B}$, kenapa berfikiran ka begitu karena sudut $\mathrm{C}$ itu kan 60 , terus sudut $\mathrm{B}$ itu 30 berarti otomatis sudut $\mathrm{C}$ itu 2 kali 30 , jadi 60-begitu.

Terus berdasarkan konsep itu untuk mendapatkan nilai maka itu juga berlakuu di segitiga dimana $\mathrm{AB}=2 \mathrm{AC}$. Maka $\mathrm{AB}=2 \times 4=8$. Nah, disini kenapa bilang ka $\mathrm{AB}$ itu $=2$ kali $\mathrm{AC}$, karena kan diketahui di soal $\mathrm{AB}$ itu 8, terus $\mathrm{AC}$ itu 4, jadi berfikirma disitu kalau misalnya ini sudut AB 2 kalinya sudut AC.

Pada Transkrip 1, subjek menjabarkan bahwa jawaban Falih benar, menurutnya sudut $\mathrm{C}=2 \mathrm{~B}$ karena besar sudut $\mathrm{C}$ adalah $60^{\circ}$ dan sudut $\mathrm{B} 30^{\circ}$, yang berarti besar sudut $\mathrm{C}$ itu 2 kali $30^{\circ}$ yakni 
$60^{\circ}$. Berdasarkan konsep yang sama, untuk mendapatkan nilai $\mathrm{AB}$, berlaku $\mathrm{AB}=2 \mathrm{x} \mathrm{AC}$. Maka $\mathrm{AB}=2 \times 4=8$ (S1-W065). Subjek tidak mengingat sifat-sifat dan perbandingan apa saja yang berlaku pada segitiga khususnya dalam hal ini segitiga siku-siku. Materi yang diingat oleh subjek terpaparkan pada Transkrip 2.

\section{TRANSKRIP 2.}

P1-W081 Tau nda caranya misalnya ini sudutnya diketahui ji 33nya, terus ini diketahui panjangnya $\mathrm{AC} 4$-bisa nda dihitung panjangnya $\mathrm{AB}$ ?

S1-W081 Setauku nah, antara pake aturan sinus atau cosinus- kulupa ki rumusnya

Pada Transkrip 2 subjek mengatakan bahwa untuk mengetahui panhang $\mathrm{AB}$, apabila diketahui panjang $\mathrm{AB}$, maka dapat digunakan aturan sinus atau cosinus, ketika ditanya lebih lanjut subjek justru tidak mengingat formula dari konsep sinus ataupun cosinus. Kutipan P1-W081 menunjukkan bahwa sebenarnya subjek sudah pernah mendapatkan materi yang seharusnya digunaan untuk menjawab soal pertama, namun tidak mengingat dengan baik materi atau konsep tersebut.

Hasil tes PCK dan wawancara pada kedua subjek menunjukkan bahwa subjek pernah mendapatkan materi yang diberikan namun sudah tidak mengingat materi tersebut atau hanya mengingat konsep secara samar, sehingga jawaban tidak dihasilkan dengan formula yang spesifik.

\section{Indikator Pengetahuan Pedagogi}

Sebaran hasil kerja subjek terkait indikator PCK pengetahuan pedagogi akan disajikan pada Tabel 4.

TABEL 4. Persentase Indikator Pengetahuan Pedagogi.

Point yang diberikan

\begin{tabular}{ccccccc} 
& \multicolumn{2}{c}{3 Poin } & \multicolumn{2}{c}{ 2 Poin } & \multicolumn{2}{c}{ 1 Poin } \\
\cline { 2 - 7 } & Jumlah & Persentase & Jumlah & Persentase & Jumlah & Persentase \\
\hline Problem 1-B & 0 & $0 \%$ & 28 & $62,3 \%$ & 17 & $37,8 \%$ \\
Problem 2-A & 19 & $42,2 \%$ & 26 & $57,8 \%$ & 0 & $0 \%$ \\
Problem 3-A & 7 & $15,6 \%$ & 35 & $77,8 \%$ & 3 & $6,67 \%$ \\
Problem 3-C & 2 & $4 \%$ & 5 & $11,1 \%$ & 38 & $84,4 \%$ \\
Problem 4-B & 3 & $6,67 \%$ & 15 & $33,3 \%$ & 27 & $60 \%$ \\
\hline
\end{tabular}

Tabel 4 menunjukkan persentase pada pengetahuan subjek terkait pedagogi berada pada angka dibawah 50\%. Pada paparan jawabannya, subjek lebih sering berencana untuk menjelaskan kembali terkait materi yang tidak dimengerti siswa pada soal, tanpa mempertimbangan titik point kesalahan atau miskonsepsi peserta didik mereka.

Berikut disajikan paparan jawaban subjek terkait pemahaman materi..

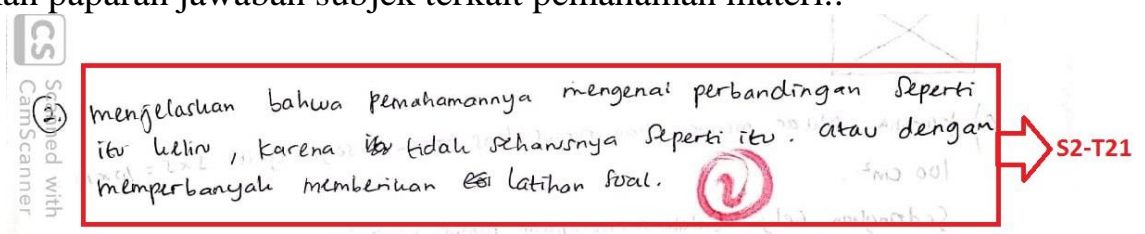

GAMBAR 2. Paparan Jawaban Subjek A-Soal No 2

Subjek pada Gambar 2 akan menjabarkan bahwa untuk memperbaiki kesalahpahaman yang dimiliki oleh siswa, subjek mengemukakan bahwa cukup menjelaskan bahwa pemahamannya 
keliru dan tidak seharusnya seperti itu (S2-T21), atau dengan memperbanyak latihan soal. Hal itu juga sejalan dengan hasil wawancara yang dilakukan pada Transkrip 3.

\section{TRANSKRIP 3}

P2-W034 Jadi karena Falih salah dan misalnya Ais dihadapkan pada siswa yang mempunya i pendapat seperti Falih, bagaimana cara menyadarkan kesalahpahaman yang dialami?

S2-W034 Saya akan mejelaskan kembali dengan memperlihatkan salah satu rumus menganai yang berkaitan dengan sudut

P2-W035 Berarti disini pemahaman yang tidak dipahami ini apa maksudnya?

S2-W035 Tidak dipahami berarti itu Falih tidak tau kalo misalnya ada rumus yang bisa kita gunakan untuk menentukan sudut yang tidak diketahui atau sisi yang tidak diketahui.

Pada transkrip 3, subjek mengatakan bahwa ia akan menjelaskan kembali terkait materi PD yang salah dan juga menggunakan media untuk menjelaskan (S2-W085). Menjelaskan ulang materi ke subjek adalah hal yang sering di lakukan oleh pendidik. Namun, ada hal yang lebih crusial yakni menitik beratkan penjelasan pada sumber misskonsepsi yang dimiliki oleh subjek. Metode menjelaskan bisa dengan menggunakan konsep scaffolding, atau dengan menggunakan perumpamaan-perumpamaan yang terkait dengan kehidupan sehari-hari.

\section{Indikator Pengetahuan Subjek Terhadap Pemahaman Peserta Didiknya.}

Sebaran hasil kerja subjek terkait indikator PCK pengetahuan subjek terkait pemahaman peserta didik akan disajikan pada Tabel 4.

TABEL 4. Persentase Indikator Pemahaman Subjek terkait Peserta Didik.

\begin{tabular}{ccccccc}
\hline & \multicolumn{5}{c}{ Point yang diberikan } \\
\cline { 2 - 7 } & \multicolumn{2}{c}{ 3 Poin } & \multicolumn{3}{c}{ 2 Poin } & \multicolumn{2}{c}{ 1 Poin } \\
\cline { 2 - 7 } & Jumlah & Persentase & Jumlah & Persentase & Jumlah & Persentase \\
\hline Problem 1 - C & 1 & $2 \%$ & 22 & $48,9 \%$ & 22 & $48,9 \%$ \\
Problem 1 - D & 0 & $0 \%$ & 21 & $46,7 \%$ & 24 & $53,3 \%$ \\
Problem 2 - C & 8 & $17,8 \%$ & 16 & $35,6 \%$ & 21 & $46,7 \%$ \\
Problem 3 - D & 2 & $4 \%$ & 2 & $4 \%$ & 41 & $91,1 \%$ \\
Problem 4 - C & 0 & $0 \%$ & 13 & $29,9 \%$ & 32 & $71,1 \%$ \\
Problem 4 - D & 0 & $0 \%$ & 15 & $33,3 \%$ & 30 & $66,7 \%$ \\
\hline
\end{tabular}

Pada aspek pengetahuan subjek terkait peserta didik, presentase subjek mendapat poin sempurna sangat kurang. Hal ini disebabkan karena fokus analisis subjek terhadap peserta didiknya belum menyeluruh dan belum menyentuh akar dari misskonsepsinya. Salah satu paparan jawaban subjek terkait peserta didiknya dipaparkan pada Gambar 3.

Pada gambar 3, subjek berpendapat bahwa Falih beranggapan apabila salah satu suduh memiliki panjang sisi, maka apabila besar sudutnya menjadi dua kali lebih besar, maka panjang sisi juga akan 2 kali lebih panjang (S2-T12). Hal tersebut benar, namun alasan paling dasar mengapa peserta didik beranggapan demikian adalah karena subjek mengira bahwa ada besar sudut memengaruhi panjang sisi. Salah satu paparan jawaban terkait pengetahuan subjek disajidkan pada Transkrip 5. 


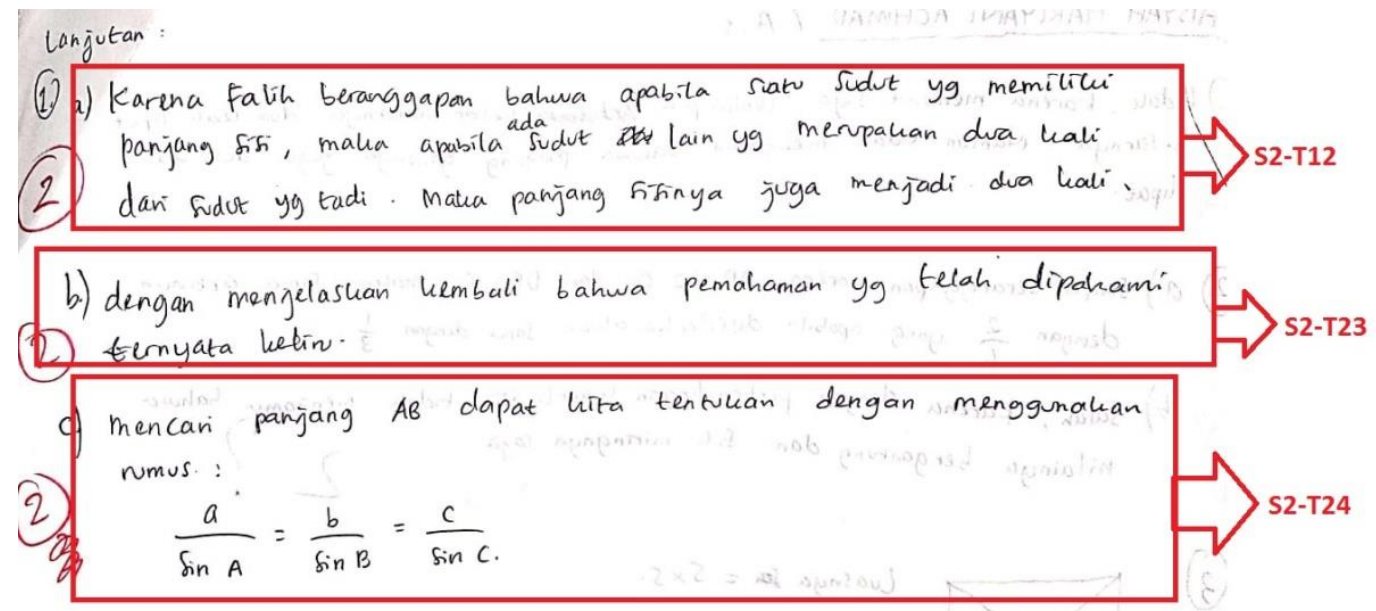

TRANSKRIP 5

GAMBAR 3. Paparan Jawaban Subjek B-Soal No 1.

P2-W032 Iya kenapa bisa Falih menganggap demikian? Apa yang ada di fikirannya Falih?

S2-W032 Karena mungkin Falih menganggap kan ini panjangnya 4, AC nya 4 terus AB nya 8 jadi kemungkinan itu kalo misalnya $C$ nya sudah diketahui 60 , ternyata $A C$ nya kan 4-dia dapat 60, AB nya 8, berarti kira-kira AB nya brp? Dia blgmi 30.

P2-W033 Hm dia berfikir kalo...

S2-W033 Iya karena disini dia liat oh kalo 460 berarti kalo 8 itu berapa?

Menurut subjek, Falih menganggap demikian karena sudutnya mmenunjukkan demikian, otomatis siisnya juga akan menunjukkan hal yang sama dengan sudut (S2-W032). Hal ini benar namun ada kemungkinan lain mengapa Falih beranggapa demikian, Falih beranggapan demikian karena mengaitkannya dengan konsep sudut pusat lingkaran atau sudut keliling lingkaran yang sudut-sudut tersebut mempunyai proporsi yang sama dengan panjang tali busurtali busur di hadapannya.

Berdasarkan hasil wawancara yang dilakukan, Subjek memiliki kemampuan yang baik dalam hal menginterpretasikan alasan dibalik kesalahan-kesalahan yang dialami oleh peserta didik mereka, kedua subjek menjawab dengan benar pertanyaan-pertanyaan terkait mengapa subjek memiliki pemikiran yang keliru dan atas dasar apa miskonsepsi muncul dalam fikiran mereka. Namu, jawaban yang diberikan hanya fokus pada satu jawaban saja dan tidak mempertimbangkan jawaban lain yang memungkinkan peserta didik mengalami misskonsepsi tersebut.

\section{KESIMPULAN}

Kesimpulan dari penelitian ini adalah Pengetahuan Konten Pedagogi mahasiswa menunjukkan bahwa sebagian besar subjek berada pada Level sedang, yang menunjukkan bahwa subjek: (1) Memahami kesulitan siswa dan alasan siswa mengalami kesulitan tersebut, (2) Belum dapat mengajukan pertanyaan yang tepat dan berarti untuk meluruskan proses berfikir mereka, (3) Memiliki kesulitan untuk menciptakan solusi untuk meluruskan kesalahpahaman peserta didik mereka. Subjek lain juga berada pada level kurang, yang menunjukkan bahwa subjek: (1) Sulit memahami kesulitan siswa dan alasan siswa mengalami kesulitan tersebut (2) Tidak mampu memahami proses berpikir siswa dengan pertanyaan atau memiliki kemampuan untuk menciptakan solusi untuk kesulitan belajar siswa (3) Kesulitan untuk membentuk kriteria yang tepat untuk penilaian dan tidak menilai jawaban siswa sesuai dengan kriteria ini.

Penjabaran lebih lanjut pada indikator menunjukkan bahwa: (a) Pengetahuan subjek terkait materi, subjek masih belum bisa menyebutkan formula-formula yang akan dipakai. (b) Pengetahuan pedagogi, kedua hanya akan "menjelaskan kembali" materi yang dimaksud ketika 
dimnta unutk meluruskan suatu miskonsepsi. (c) Pengetahuan subjek terkait pengetahuan peserta didiknya, subjek lebih sering menjawab dengan benar terkait alasan dari kesalahpahaman peserta didiknya. apalagi saat ditunjang dengan pengetahuan subjek terkait materi yang tercakup dalam soal, namun subjek tidak mempertimbangankan kemungkinan misskonsepsi lain yang mungkin muncul.

\section{DAFTAR PUSTAKA}

Cochran, K. F., DeRuiter, J. A., \& King, R. A. (1993). Pedagogical content knowing: Anintegrative model for teacher preparation. Journal of Teacher Education, 44, 263272.

Fennema, E., \& Franke, M. L. (1992). Teachers' knowledge and its impact. In D. A. Grouws (Ed.), Handbook of research on mathematics teaching and learning (pp. 127-147). New York: Macmillan.

Grossman, P. L. (1990). The making of a teacher: Teacher knowledge and teacher education. New York: Teachers College Press.

Indirani, Fitri. 2016. Kompetensi Pedagogik Mahasiswa Dalam Mengelola Pembelajaran Tematik Integratif Kurikulum 2013 Pada Pengajaran Micro Di PGSD UAD Yogyakarta. ISSN 2406-8012.

Lim, C.S. (2007). Characteristics of mathematics teaching in Shanghai, China: through the lens of a Malaysian. Mathematics Education Research Journal, 19 (1), 77-89.

Magnusson, S., Krajcik, J., \& Borko, H. (1999). Nature, sources, and development of pedagogical content knowledge for science teaching. In J. Gess Newsome \& N. G. Lederman (Eds.), Examining pedagogical content knowledge: The construct and its implications for science education (pp. 95-132). Dordrecht, Netherlands: Kluwer.

Purwianingsih, W., Rustaman, Nuryani Y., Redjeki, Sri. 2010. Pengetahuan Konten Pedagogi (PCK) dan Urgensinya dalam Pendidikan Guru. Jurnal Pengajaran Matematika dan Ilmu Pengetahuan Alam (JPMIPA); 15(2). ISSN 1412-0917 eISSN 2443-3616

Shulman, L. S. (1986). Those who understand: Knowledge growth in teaching. Educational ResearPcher, 15(2), 4-14.

Shulman, L. S. (1987). Knowledge and teaching: Foundations of the new reform. Harvard Educational Review, 57, 1-22.

Smith, D. C., \& Neale, D. C. (1989). The construction of subject matter knowledge in primary science teaching. Teaching and Teacher Education, 5, 1-20.

Turnuklu, E.B. \& Yesildere, S. (2007). The pedagogical content knowledge in mathematics:preservice primary teachers' perspectives. IUMPST: The Journal, 1, 1 - 13.

Yasin,A. Fatah. (2008).Dimensi-Dimensi Pendidikan Islam, Malang: UIN Malang Press. 